\title{
Miarkowanie kary umownej w Kodeksie cywilnym i wybranych aktach modelowego prawa umów
}

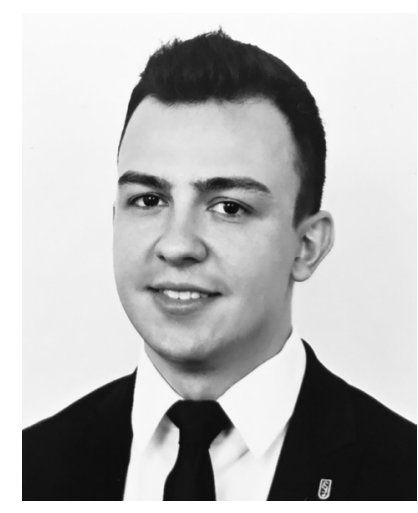

Alexander Martin Juranek

Doktorant w Katedrze Międzynarodowego Prawa Prywatnego i Handlowego Wydziału Prawa i Administracji Uniwersytetu Warszawskiego. Członek zespołu badawczego nad europejskim i polskim prawem prywatnym w Instytucie Nauk Prawnych Uniwersytetu Śląskiego. Laureat nagrody naukowej im. Profesora Waleriana Pańki za wybitne osiagnięcia naukowe. Specjalizuje się w prawie cywilnym, handlowym, prywatnym międzynarodowym $i$ konstytucyjnym.

$\triangle$ am.juranek@uw.edu.pl https://orcid.org/0000-0002-4927-8252

\section{Reduction the Specified Sum to Reasonable Amount in "Contractual Penalties Clauses" in Polish Civil Code and Selected Model Acts of Contract Law}

\begin{abstract}
This article aims synthetically to refer to discussion between Polish academiclawyers about the controversies regarding to reduction of a specified sum in "agreed or stipulated payment for non-performance" in art. 484 § 2 of Polish Civil Code. These conclusions, resulting from the analysis of Polish private law - will be referring to the same reduction-clause in three selected acts of contracts model law: UNIDROIT Principles of International Commercial Contracts, the Principles of European Contract Law and the Draft Common Frame of Reference. The last part of this article contains the conclusions de lege ferenda from comparative analysis.
\end{abstract}

Słowa kluczowe: kara umowna, miarkowanie, prawo polskie, prawo modelowe, prawo europejskie, harmonizacja

Key words: contractual penalties, reduction, Polish law, model law, European law, harmonisation

https://doi.org/10.32082/fp.v0i3(59).265

\section{Wprowadzenie.}

Aksjologiczna ratio legis miarkowania

Celem niniejszego artykułu jest omówienie najistotniejszych kwestii związanych z mechanizmem miarkowania kary umownej w prawie polskim, a następnie odniesienie tychże rozważań do zbliżonych konstrukcji wynikających z ponadnarodowych pro- jektów regulacyjnych (tzw. prawa modelowego $)^{1}$. $\mathrm{Z}$ analizy kom-

1 Na potrzeby niniejszych rozważań przeanalizowane zostaną: UNIDROIT Principles of International Commercial Contracts 2016, https://www.trans-lex.org/400120/ highlight_unidroit/unidroit-principles-of-international-commercial-contracts-2016 (dostęp 22.10.2019; 
paratystycznej wyprowadzone zostaną w dalszej kolejności szczegółowe wnioski uwzględniające zarówno wynikający z art. $484 \$ 2$ Kodeksu cywilnego ${ }^{2}$ model zastrzeżenia, jak też jego funkcjonalne „odpowiedniki” zamieszczone w wybranych do analizy aktach prawa modelowego, zwłaszcza $w$ art. 7.4.13 ust. 2 UPICC, art. 9:509 ust. 2 PECL $i$ art. III-3:712 ust. 2 DCFR. Rozważania warto rozpocząć od przypomnienia, że kara umowna w rozumieniu Kodeksu cywilnego stanowi - jak wiadomo - akcesoryjne zastrzeżenie umowne, w ramach którego strony postanawiają, że jeżeli doszłoby do niewykonania lub wykonania w sposób nienależyty zobowiązania niepieniężnego, wówczas naprawienie wynikłej stąd szkody nastąpi przez zapłatę określonej sumy ${ }^{3}$. Powołując z kolei instytucję miarkowania kary umownej, wprowadzono w element represyjno-stymulacyjnego zastrzeżenia zawartego w art. $483 \$ 1$ k.c. także przejawy tzw. prawa sędziowskiego ${ }^{4}$, powiadając, że jeżeli zobowiązanie zostało w znacznej części wykonane, dłużnik może żądać zmniejszenia kary umownej; to samo dotyczy wypadku, gdy kara umowna jest rażąco wygórowana. Zawarta w art. $484 \$ 2$ k.c. dyspozycja jest więc wyrazem dążenia prawodawcy polskiego do zapewnienia dłużnikowi ochrony przed nadmiernie dotkliwymi dla niego skutkami odpowiedzialności kontraktowej na podstawie art. 483-484 k.c., której wyrazem jest przyznanie sądowi możliwości władczego ingerowania w treść stosunku zobowiązaniowego, a tym samym modyfikowania stosunku umownego pomiędzy stronami i ograniczenie przysługującej im autonomii

dalej: Reguły UNIDROIT, UPICC); The Principles of European Contract Law, https://www.trans-lex.org/400200/_/ pecl (dostęp 22.10.2019; dalej: Zasady PECL, PECL); The Principles, Definitions and Model Rules of European Private Law, Draft Common Frame of Reference (DCFR), https://www. law.kuleuven.be/personal/mstorme/2009_02_DCFR_OutlineEdition.pdf (dostęp 30.10.2019).

2 Ustawa z dnia 23 kwietnia 1964 r. - Kodeks cywilny, Dz.U. nr 16, poz. 93; t.j. Dz.U. 2019, poz. 1145 (dalej: k.c.).

3 Definicja nawiasowa kary umownej została zawarta w art. 483 $\$ 1$ k.c.

4 Zob. W. Borysiak, Komentarz do art. 484 (w:) K. Osajda (red.), Kodeks cywilny. Komentarz. Zobowiązania. Część ogólna, t. IIIA, Warszawa 2017, nb. 31, Legalis. woli ${ }^{5}$. Ze zbliżonych, acz nietożsamych założeń co do ratio instrumentu miarkowania wyszli także twórcy tzw. modelowego prawa umów, którego wybrane akty staną się przedmiotem poniższych rozważań.

Na początku należy przypomnieć, że przyjęty w danym systemie prawa krajowego model miarkowania kary umownej najczęściej ma charakter wypadkowej dwóch zasadniczych koncepcji doktrynalnych ${ }^{6}$. Pierwsza z nich skłania się ku realizacji postulatu słuszności kontraktowej oraz sprawiedliwości odnoszonej $a$ casu. Zgodnie z jej założeniami miarkowanie kary umownej powinno dać sądowi możliwość ocenienia, czy zastrzeżona inter partes kara konwencjonalna nie jest całkowicie oderwana w swojej represyjności od faktycznie poniesionego przez wierzyciela uszczerbku majątkowego w związku z niewykonaniem lub nienależytym wykonaniem zobowiązania przez dłużnika. Wierzycielowi nie będzie więc przysługiwało prawo do dochodzenia kary umownej w tej samej wysokości, niezależnie od zakresu naruszenia powinności kontraktowych czy stopnia przyczynienia się dłużnika ${ }^{7}$. Konieczne z punktu widzenia bezpieczeństwa obrotu wydaje się zapewnienie sądowi możliwości redukcji zastrzeżonej pomiędzy stronami kary umownej z uwagi na złożoność czynników, które mogły wpłynąć na narażenie się przez dłużnika na odpowiedzialność kontraktową, a które na skutek błędnej lub pośpiesznie dokonanej oceny przyjętego w ramach umowy ryzyka nie zostały uwzględnione przez strony ${ }^{8}$. Oczywiście można by argumentować, że już na etapie składania oświadczeń woli kontraktujący mieli świadomość wysokości sankcji zastrzeżonych na wypadek niewykonania lub nienależytego wykonania poszczególnych obowiązków czy też całości zobowiązania, jednak z uwagi na konieczność realizacji ww. zasady sprawiedliwości, słuszności, a także dobrej wiary czy współżycia społecznego argumenty wywodzone z tej podstawy wydają się nieprzekony-

\footnotetext{
5 Tak też P. Drapała, A. Olejniczak, Dodatkowe zastrzeżenia umowne (w:) E. Łętowska (red.), System prawa prywatnego. Prawo zobowiazań - część ogólna, t. 5, Warszawa 2013, s. 1157.

6 Tamże.

7 Tamże.

8 Tamże.
} 
wające ${ }^{9}$. Na podobne racje jurydyczne uzasadniające przyjęty w k.c. model miarkowania wskazuje się także w odniesieniu do zbliżonej regulacji historycznego już art. 85 Kodeksu zobowiązań ${ }^{10}$.

Druga z reprezentowanych koncepcji zakłada konieczność całkowitego oderwania się od wspomnianych kwantyfikatorów aksjologicznych mogących ingerować w stosunek zobowiązaniowy i stanowić podstawę miarkowania kary umownej ${ }^{11}$. Jej przedstawiciele skłaniają się do bezwzględnego poszanowania autonomii woli stron, w szczególności z uwagi na szeroko rozumianą zasadę swobody kontraktowej, negując tym samym możność władczego ingerowania w zastrzeżenie o karze wadialnej w ogóle albo nakazując czynienie tego w sposób nad wyraz powściągliwy. Stanowisko swoje wywodzą ze zbiegu zasad pacta sunt servanda oraz volenti non fit iniuria, zaznaczając, że wyłącznie uprawnionymi do modyfikacji postanowień umownych w omawianym zakresie są strony, a nie sąd. Przedstawiciele tego poglądu przywołują także argu-

9 Tak J. Szwaja, Kara umowna według Kodeksu cywilnego, Warszawa 1967, s. 135. Autor ten zwraca uwagę, że w pewnych wypadkach wysokość kary może naruszać zasady leżące u podstaw wykonywania zobowiązań, które zostały przywołane powyżej, ale również wskazuje „zasadę rozrachunku gospodarczego", która co prawda nie jest już raczej dzisiaj przywoływana w piśmiennictwie jako jedna z zasad reżimu kontraktowego, ale miała znaczenie w obrocie gospodarczym uspołecznionym.

10 Rozporządzenie Prezydenta Rzeczypospolitej Polskiej z 27 października 1933 r. - Kodeks zobowiązań, Dz.U. 1933, nr 82, poz. 598 ze zm. (dalej: k.z.); zob. także R. Longchamps de Berier, Zobowiązania, Poznań 1948, s. 191; R. Longchamps de Berier, Uzasadnienie projektu kodeksu zobowiązań z uwzględnieniem ostatecznego tekstu tego kodeksu, Warszawa 1935, s. 112.

11 Zob. P. Drapała, A. Olejniczak, Dodatkowe zastrzeżenia..., s. 1158 oraz cyt. tam autorzy; a także W. Canaris, Verfassungs- und europarechtliche Aspekte der Vertragsfreiheit (w:) Wege und Verfahren des Verfassungslebens. Festschrift für Peter Lerche zum 65. Geburtstag, München 1993, s. 886; K. Lindacher, Phänomenologie der Vertragsstrafe. Vertragsstrafe, Schadensersatzpauschalierung und schlichter Schadensbeweisvertrag, Würzburg 1972, s. 107-108 i cyt. tam piśmiennictwo. ment, że nie można uznać kary umownej wymagalnej ${ }^{12}$ z uwagi na niewykonanie lub nienależyte wykonania zobowiązania za nazbyt wygórowaną, ponieważ nie spełniła ona swojej prewencyjnej roli. Niemniej kondensacja całości podnoszonych tutaj argumentów do ogólnego założenia, że instrument miarkowania kary umownej winien być stosowany z zachowaniem odpowiedniej ostrożności - słusznie została zaaprobowana przez większość przedstawicieli polskiej doktryny ${ }^{13}$. Warto przy tym wskazać, że niektórzy autorzy - co do

12 Zakłada się tu pewien skrót myślowy; chodzi o sytuację, w której mimo skutecznego zastrzeżenia kary umownej na okoliczność niewykonania lub nienależytego wykonania zobowiązania, i tak doszło do tegoż niewykonania lub wykonania nienależytego, w związku z czym kara wadialna nie mogła być aż tak surowa, skoro i tak zobowiązanie nie zostało wykonane, a tym samym jej funkcja prewencyjna została niezrealizowana.

13 Tak m.in. J. Dąbrowa (w:) Z. Radwański, System prawa cywilnego, t. 3, cz. 1: Prawo zobowiązań - część ogólna, Warszawa 1981, s. 833 i n.; W. Popiołek, Komentarz do art. 484 (w:) K. Pietrzykowski (red.), Kodeks cywilny, t. 2: Komentarz. Art. 450-1088, Warszawa 2018, nb. 10 Legalis; K. Zagrobelny, Komentarz do art. 484 (w:) E. Gniewek, P. Machnikowski (red.), Kodeks cywilny. Komentarz, Warszawa 2017, s. 1023; a także J. Jastrzębski, Glosa do uchw. SN (7) z 06.11.2003 r., sygn. akt III CZP 61/03, „Orzecznictwo Sądów Polskich” 2004, nr 9, poz. 115. Odmiennie zob. W. Borysiak, Komentarz do art. 484 (w:) K. Osajda (red.), Komentarz..., nb. 32; M. Lemkowski, Komentarz do art. 484 (w:) M. Gutowski (red.), Kodeks cywilny, t. 2: Komentarz do art. 353-626, Warszawa 2019, nb. 5, w którym autor ten przyjmuje, że „twierdzenie o wyjątkowym charakterze miarkowania kary umownej (...) obecnie ulega znaczącej dezaktualizacji, przede wszystkim $\mathrm{z}$ uwagi na znaczne zmiany w praktyce funkcjonowania kar umownych w porównaniu do czasu, kiedy poglądy te były formułowane, a więc poprzedniego systemu społeczno-gospodarczego. Z żadnego przepisu prawa nie wynika, aby instytucja $\mathrm{z}$ art. $484 \$ 2$ k.c. miała mieć z jakichkolwiek powodów charakter wyjątkowy i aby musiała być stosowana szczególnie ostrożnie. To, że instytucja ta ulokowana została w obszarze uznania sędziowskiego nie przesądza w żadnym razie, że należy z niej korzystać rzadko. Przeciwnie, należy stosować art. $484 \$ 2$ k.c. w każdym przypadku, ilekroć zobowiązanie zostało w znacznej części wykonane, jak i wtedy, gdy zastrzeżona przez strony kara okazuje się rażąco wygórowana”. 
zasady niepodzielający poglądu o konieczności zachowania ostrożności przy korzystaniu $\mathrm{z}$ instrumentu wynikającego $\mathrm{z}$ art. $484 \$ 2$ k.c. - na obowiązek taki wskazują wyłącznie w przypadku uczestników obrotu profesjonalnego ${ }^{14}$.

\section{Konstrukcja jurydyczna i przesłanki miarkowania kary umownej w prawie polskim}

\subsection{Konstrukcja jurydyczna}

Jak wspomniano, sąd, stosując na podstawie art. $484 \$ 2$ k.c. instrument miarkowania kary umownej, uprawniony jest do władczej ingerencji w postanowienie kontraktowe rozstrzygające o wysokości tejże kary, która może zostać zmniejszona mocą orzeczenia mającego charakter konstytutywny ze skutkiem ex tunc ${ }^{15}$. Warto nadmienić, że rozstrzygnięcie pomniejszające zastrzeżoną wysokość kary jest jedynym uprawnieniem sądu w tym zakresie. Nie jest dopuszczalne dokonanie chociażby zamiany świadczenia na inne, rozłożenia ustalonej kwoty na raty czy zmiana terminu zapłaty etc. ${ }^{16}$ Zgodnie z zasadą exceptiones non sunt extendendae przyjmuje się, że z uwagi na wyjątkowy charakter przepisu upoważniającego do władczej ingerencji w treść stosunku zobowiązaniowego mocą art. $484 \S 2$ k.c. nie powinno się jego dyspozycji odnosić do świadczeń niebędących karami umownymi (podobnie względem m.in. art. $357^{1}$, art. $358^{1} \$ 3$, art. 388 k.c. $)^{17}$.

W literaturze i orzecznictwie nie budzi wątpliwości wykładnia literalna przepisu art. $484 \$ 2$ k.c., w którym expressis verbis stwierdzono, że „dłużnik może żądać zmniejszenia kary umownej”. Prowadzi to do

14 Tak P. Drapała, A. Olejniczak, Dodatkowe zastrzeżenia..., s. 1160 in fine i 1161.

15 Zob. J. Szwaja, Kara umowna..., s. 136; J. Jastrzębski, Kara umowna, Kraków 2006, s. 307-309; W. Popiołek, Komentarz... (w:) K. Pietrzykowski (red.), Kodeks cywilny, nb. 6; K. Korzan, Orzeczenia konstytutywne w postępowaniu cywilnym, Warszawa 1972, s. 195; por. także wyrok SN z 23.05.2013 r., sygn. akt IV CSK 644/12, Legalis; wyrok SA w Szczecinie z 18.01.2017 r., sygn. akt I ACa 750/16, Legalis.

16 Tak P. Drapała, A. Olejniczak, Dodatkowe zastrzeżenia..., s. 1158.

17 Tamże. wniosku, że przeprowadzenie procesu miarkowania kary umownej odbywa się wyłącznie na wniosek dłużnika ${ }^{18}$. W drodze analogii należy opowiedzieć się także za przyznaniem tego uprawnienia osobom trzecim ponoszącym odpowiedzialność za zapłatę kary umownej przez dłużnika, którym przepisy prawa przyznają możność korzystania z zarzutów przysługujących dłużnikowi (np. art. $883 \$ 1$ w zw. z art. $484 \$ 2$ k.c.). Co prawda dłużnik może podjąć także obronę innego rodzaju, kwestionując chociażby skuteczność zastrzeżenia kary umownej, niewystąpienie przesłanek powstania roszczenia o jej zapłatę czy podnosząc zarzut jej przedawnienia, niemniej wyłącznie do niego należy kwestia skorzystania z prawa żądania redukcji kary wadialnej. Miarkowanie nigdy nie może zostać przeprowadzone $\mathrm{z}$ urzędu ${ }^{19}$.

Całkowicie odrębny problem stanowi także forma i sposób skutecznego skorzystania z żądania miarkowania kary umownej przez dłużnika. W orzecznictwie Sądu Najwyższego wyodrębniły się w tej kwestii dwa całkowicie rozbieżne stanowiska, z których pierwsze przyjmuje, że „żądanie dłużnika oddalenia powództwa o zapłatę kary umownej zawiera implicite wniosek o zmniejszenie tej kary" ${ }^{\text {20 }}$. Pogląd ten został wielokrot-

$18 \mathrm{Za}$ takim rozumieniem art. $484 \$ 2$ in principio przemawia także wykładnia historyczna - por. R. Longchamps de Berier, Zobowiązania, s. 191; L. Domański, Instytucje kodeksu zobowiązań. Komentarz teoretyczno-praktyczny. Część ogólna, t. 2, Warszawa 1936, s. 393; J. Szwaja, Kara umowna..., s. 136. Autor ten stwierdza także, że „zmniejszenie kary na podstawie przepisów regulujących system pieniężny, będące skutkiem np. przerachowania zobowiązań, nie podpadnie pod pojęcie miarkowania (...). Wątpliwe jest, czy organ orzekający może zmniejszyć karę umowną $\mathrm{z}$ urzędu (...). Ingerencja organów orzekających w umowne stosunki stron powinna być ograniczona do tych wypadków, kiedy zezwalają na nią przepisy”.

19 Tak m.in. J. Szwaja, Kara umowna..., s. 136; W. Popiołek, Komentarz... (w:) K. Pietrzykowski (red.), Kodeks cywilny, nb. 12 oraz cyt. tam autorzy.

20 Zob. wyrok SN z 14.07.1976 r., sygn. akt I CR 221/76, OSNC 1974, nr 4, poz. 76, w którym SN wywiódł, że „dłużnik żąda tego [tj. w trybie art. $484 \$ 2$ k.c. - AMJ] zmniejszenia nie tylko wtedy, kiedy nie kwestionuje obowiązku zapłaty kary umownej, a tylko wnosi o zmniejszenie jej wysokości, lecz także wtedy, kiedy kwestionuje obowiązek zapłaty kary 


\section{Na dłużniku ciąży obowiązek ujawnienia}

\section{swego żądania redukcji.}

nie powtórzony w orzecznictwie $\mathrm{SN}^{21}$. Jednocześnie w piśmiennictwie zdaje się przeważać krytyka tego stanowiska $^{22}$, choć ma ono swoich zwolenników ${ }^{23}$,

umownej i dlatego wnosi o nieuwzględnienie roszczenia o zapłatę tej kary, we wniosku bowiem o nieuwzględnienie roszczenia mieści się wniosek „o mniej”, tj. i żądanie zmniejszenia kary umownej [podkr. - AMJ]”.

21 Zob. m.in. wyrok SN z 25.3.1998 r., sygn. akt II CKN 660/97, Legalis; wyrok SN z 16.7.1998 r., sygn. akt I CKN 802/97, OSNC 1999, nr 2, poz. 32; wyrok SN z 4.12.2003 r., sygn. akt II CK 271/02; wyrok SN z 12.5.2006 r., sygn. akt V CSK 55/06; wyrok SN z 27.2.2009 r., sygn. akt II CSK 511/08, Legalis; wyrok SN z 22.1.2010 r., sygn. akt V CSK 217/09, Legalis.

22 Por. m.in. K. Zagrobelny, Komentarz... (w:) E. Gniewek, P. Machnikowski (red.), Kodeks cywilny..., s. 1024; T. Wiśniewski, Komentarz do art. 484 (w:) J. Gudowski (red.), Kodeks cywilny. Komentarz, t. 3: Zobowiązania. Część ogólna, Warszawa 2017, s. 927; W. Popiołek, Komentarz... (w:) K. Pietrzykowski (red.), Kodeks cywilny, nb. 12; Z. Gawlik, Komentarz do art. 484 (w:) A. Kidyba (red.), Kodeks cywilny. Komentarz. Zobowiązania. Część ogólna, t. 3, Warszawa 2014, nb. 7-11, LEX.

23 Zob. w szczególności P. Drapała, A. Olejniczak, Dodatkowe zastrzeżenia..., s. 1159; a także P. Drapała, Glosa do wyroku SN z 23 marca 2006 r., sygn. akt IV CSK 89/05, „Przegląd Sądowy” 2007, nr 5, s. 122; M. Pyziak-Szafnicka, Kilka uwag na temat modelu kary umownej (w:) J. Gudowski, K. Weitz (red.), Aurea praxis. Aurea theoria. Księga pamiątkowa ku czci Profesora Tadeusza Erecińskiego, t. 2, Warszawa 2011, s. 2492. W orzecznictwie zob. m.in. wyrok SN z 18.6.2003 r., sygn. akt II CKN 240/01, Legalis; wyrok SN z 6.2.2008 r., sygn. akt II CSK 421/07, Legalis; wyrok SN z 26.11.2008 r., sygn. akt III CSK 168/08, Legalis; wyrok SN z 23.7.2014 r., sygn. akt V CSK 503/13, Legalis; wyrok SN z 8.3.2013 r., sygn. akt III CSK 193/12, Legalis; wyrok SA w Rzeszowie z 15.11.2012 r., sygn. akt I ACa 330/12; wyrok SA we Wrocławiu z 2.2.2012 r., sygn. akt I ACa 1392/11, Legalis; wyrok SA w Warszawie z 8.10.2014 r., sygn. akt VI ACa 1660/13, Legalis; wyrok SA w Lublinie z 9.4.2014 r., sygn. akt I ACa 700/13, Legalis; wyrok SA w Lublinie z 12.2.2014 r., sygn. akt I ACa 680/13, Legalis; wyrok SA w Lodzi z 4.7.2013 r., którzy podnoszą, że owo zapatrywanie doskonale realizuje w sobie cel i funkcję instytucji miarkowania, likwidując zbyteczny formalizm i w znacznie lepszym stopniu przyczyniając się do urzeczywistniania zasady słuszności kontraktowej. Drugie stanowisko zakłada, że na dłużniku jako uprawnionym w rozumieniu art. $484 \$ 2$ k.c. do złożenia wniosku o uruchomienie procedury miarkowania ciąży obowiązek ujawnienia swego żądania, przy czym nie musi to być sformułowany wprost wniosek procesowy. Wystarczy jeżeli w toku postępowania dłużnik - wnosząc o oddalenie powództwa - wskaże także rażące wygórowanie kary umownej ${ }^{24}$. Stanowisko to znajduje uzasadnienie zarówno z punktu widzenia sytuacji prawnej wierzyciela, który poza implikacjami majątkowymi wynikającymi z niewykonania lub nienależytego wykonania zawartej z dłużnikiem umowy ponosiłby każdorazowo konsekwencje ,automatycznego uruchomienia” żądania obniżenia kary umownej wraz ze złożeniem wniosku procesowego o oddalenie powództwa przez dłużnika, jak i z punktu widzenia samego zobowiązanego, bowiem zarówno wymaga to znajomości jego faktycznego położenia procesowego, jak i nie stanowi żadnego formalnoprawnego obciążenia w postaci konieczności sporządzania dodatkowych wniosków, ograniczając się wyłącznie do konieczności odniesienia się przez dłużnika do rażącego wygórowania kary. W tym znaczeniu z pewnością oddaje to wyraz zasadzie słuszności kontraktowej, równouprawniając obie strony stosunku obligacyjnego.

sygn. akt I ACa 135/13, Legalis; wyrok SA w Szczecinie z 24.1.2013 r., sygn. akt I ACa 726/12, Legalis; wyrok SA w Białymstoku z 16.10.2017 r., sygn. akt I ACa 353/17, Legalis; wyrok SA w Białymstoku z 18.5.2017 r., sygn. akt I ACa 1040/16, Legalis; wyrok SA w Katowicach z 25.7.2016 r., sygn. akt V ACa 937/15, Legalis; wyrok SA w Warszawie z 19.1.2016 r., sygn. akt VI ACa 1216/15, Legalis; wyrok SA w Krakowie z 9.12.2014 r., I ACa 1269/14, Legalis.

24 Tak W. Popiołek, Komentarz... (w:) K. Pietrzykowski (red.), Komentarz..., nb. 12 oraz pow. tam orzecznictwo. 
Dłużnik może także wykorzystać przysługujące mu żądanie miarkowania kary umownej jako uprawnienie o charakterze prewencyjnym w tym sensie, że może wytoczyć powództwo o ukształtowanie stosunku prawnego w trybie art. 189 k.p.c. ${ }^{25}$, w którym domagać się będzie obniżenia wysokości zastrzeżonej w umowie kary, i to jeszcze przed wystąpieniem przez wierzyciela do wysokości równej poniesionej przez wierzyciela szkodzie $^{29}$. Przyjęcie odmiennego poglądu ${ }^{30}$ prowadziłoby do całkowitego pominięcia wspomnianej w zdaniu poprzedzającym funkcji, która ma generować sankcyjny charakter zastrzeżenia w stosunku do dłużnika niewykonującego lub wykonującego nienależycie swoje zobowiązanie ${ }^{31}$.

\section{Miarkowanie kary umownej w obrocie} profesjonalnym powinno mieć charakter szczególny i wyjątkowy, zaś redukcja „do zera” jest niedopuszczalna niezależnie od sfery obrotu.

z roszczeniem o jej zapłatę ${ }^{26}$. Tym sposobem uprawnienie dłużnika wynikające $\mathrm{z}$ art. $484 \$ 2$ k.c. wykładane jest sensu largo, wychodząc poza ramy wyłącznie zarzutu procesowego. Orzeczenie wydane przez sąd w trybie art. 189 k.p.c. w zw. z art. $484 \$ 2$ k.c. również będzie miało charakter konstytutywny ${ }^{27}$. Zastosowanie przez sąd miarkowania kary umownej, uwzględniając ad casum funkcję represyjną, nie może jednak doprowadzić do całkowitego zwolnienia dłużnika z obowiązku jej zapłaty ${ }^{28}$ czy też zredukowania kary

25 Ustawa z dnia 17 listopada 1964 r. - Kodeks postępowania cywilnego, Dz.U. nr 43, poz. 296, t.j. z dn. 19.07.2019, Dz.U. 2019, poz. 1460 (dalej: k.p.c.).

26 Zob. P. Drapała, A. Olejniczak, Dodatkowe zastrzeżenia..., s. 1159.

27 Tamże.

28 Zob. W. Popiołek, Komentarz... (w:) K. Pietrzykowski (red.), Komentarz..., nb. 10; P. Drapała, A. Olejniczak, Dodatkowe zastrzeżenia..., s. 1166. A także SN w wyroku z 04.12.2003 r., sygn. akt II CK 271/02; wyrok SA w Katowicach z 12.01.2017 r., sygn. akt V ACa 492/16, POSP; wyrok SA w Białymstoku z 22.12.2016 r., sygn. akt I ACa 591/16, POSP; wyrok SA w Katowicach z 28.06.2001 r., sygn. akt I ACa 295/01, PG 2002, nr 10. Odmiennie jednak W. Borysiak, Funkcje kary umownej w świetle uchwały składu siedmiu sędziów Sądu Najwyższego z 6 listopada 2003 r. (III CZP 61/03), „Palestra” 2006, nr 7-8, s. 53; M. Pyziak-Szafnicka,
Odmienne stanowiska w literaturze pojawiają się także względem konieczności „urzeczywistnienia się” obowiązku zapłaty kary umownej, rozumianego jako zaistnienie ustalonych w umowie przesłanek powodujących powstanie po stronie wierzyciela roszczenia o zapłatę kary umownej. Z punktu istoty niniejszych rozważań warto tylko przypomnieć, że część piśmiennictwa opowiada się za miarkowaniem kary wadialnej wyłącznie „już należnej” wierzycielowi ${ }^{32}$, druga część z kolei prezentuje pogląd, zgodnie z którym art. $484 \S$ 2 k.c. nie daje verba legis żadnych podstaw, aby dokonać ograniczenia sądowej kontroli jedynie do tych kar umownych, względem których przesłanki roszczenia o ich zapłatę (a tym samym obowiązku świadczenia

Kilka uwag na temat... (w:) J. Gudowski, K. Weitz (red.), Aurea praxis..., s. 2251. A także orzecznictwo - zob. wyrok SA w Szczecinie z 11.10.2012 r., sygn. akt I ACa 518/12.

29 Zob. wyrok SN z 14.04.2005 r., sygn. akt II CK 626/04, Legalis; wyrok SA w Krakowie z 12.02.2015 r., sygn. akt I ACa 1739/14 Legalis.

30 Redukcję kary umownej do zera na skutek jej miarkowania dopuszcza się chociażby w doktrynie niemieckiej, zob. V. Rieble, Staudingers Kommentar zum Bürgerlichen Gesetzbuch, t. 2, Berlin 1994, s. 370 .

31 Tak też P. Drapała, A. Olejniczak, Dodatkowe zastrzeżenia..., s. 1164-1165 in principio.

32 Tak J. Szwaja, Kara umowna..., s. 137. 
przez dłużnika) zostały urzeczywistnione ${ }^{33}$. Zapatrywania te mają znaczenie przy ustalaniu momentu wymagalności kary umownej i na etapie oceny dopuszczalności miarkowania tejże po zwolnieniu się przez dłużnika z obowiązku świadczenia przez jej zapłatę.

Co ważne, wszelkie postanowienia umowne, które w jakikolwiek sposób prowadziłyby do unicestwienia prawa do żądania miarkowania kary umownej przez dłużnika, jak też wszelkie zastrzeżenia owo prawo in minori modyfikujące - objęte będą bezwzględną nieważnością $\mathrm{z}$ uwagi na pozostawanie w sprzeczności z normami kogentnymi ${ }^{34}$. Wymaga zaznaczenia, że poprzednio obowiązujący art. $85 \$ 2$ k.z. expres sis verbis wskazywał na niemożność zrzeczenia się możliwości miarkowania kary umownej w odrębnej umowie. Na podobnym stanowisku stały też piśmiennictwo $^{35}$ i judykatura ${ }^{36}$.

Odrębny problem stanowi możliwość zrzeczenia się przez dłużnika prawa do żądania miarkowania kary umownej w sposób, który wykluczałby zastosowanie instytucji z art. $484 \$ 2$ k.c. względem stosunku łączącego debitora z wierzycielem. Przeciwko możliwości dokonania takiego zrzeczenia zarówno przez czynność jednostronną, jak i w umowie powołuje się zakwalifikowanie miarkowania kary do prawa sędziowskiego, w którego dyskrecjonalność stronom ingerować nie wolno ${ }^{37}$.

33 Tak P. Drapała, A. Olejniczak, Dodatkowe zastrzeżenia..., s. 1160.

34 Tak też w szczególności por. W. Borysiak, Komentarz do art. 484 (w:) K. Osajda (red.), Komentarz..., nb. 33; T. Wiśniewski, Komentarz do art. 484 (w:) J. Gudowski (red.), Kodeks cywilny..., nb. 6; M. Lemkowski, Komentarz do art. 484 (w:) M. Gutowski (red.), Kodeks cywilny..., nb. 3; W. Popiołek, Komentarz... (w:) K. Pietrzykowski (red.), Kodeks cywilny..., nb. 6; P. Drapała, A. Olejniczak, Dodatkowe zastrzeżenia..., s. 1161. Podobnie także orzecznictwo por. wyrok SN z 13.02.2014 r., sygn. akt V CSK 45/13, OSP $2015, \mathrm{nr} 6$, poz. $56 \mathrm{z}$ aprobującymi uwagami w glosie A. Orzeł, tamże, s. 862.

35 Tak m.in. R. Longchamps de Berier, Zobowiązania..., s. 191 i 198; J. Namitkiewicz, Kodeks zobowiązań. Komentarz dla praktyki, t. 1, Łódź 1949, s. 125.

36 Tak SN w uzasadnieniu wyroku z 28.6.1938 r., sygn. akt C II 3313/37, PPA 1938, poz. 305.

37 Zob. W. Borysiak, Komentarz do art. 484 (w:) K. Osajda (red.), Komentarz..., nb. 34 .
W odniesieniu do zarzutu, który jest już możliwy do podniesienia przez dłużnika przed sądem, a więc kiedy spełniły się przesłanki do zasądzenia kary umownej uprawniony debitor może w takiej sytuacji albo w ogóle nie składać wniosku o przeprowadzenie miarkowania kary umownej, albo też nie wykazywać przesłanek uzasadniających przeprowadzenie rzeczonej procedury przez sąd. Zwolennicy drugiego zapatrywania uznają, że jednostronne zrzeczenie się zarzutu miarkowania kary umownej jest dopuszczalne, jednak wyłącznie w odniesieniu do zarzutu, z którego dłużnik może już skorzystać $^{38}$. W obu stanowiskach zgodnie zauważono, że dokonanie tzw. niewłaściwego uznania roszczenia o karę umowną (art. $123 \$ 1$ pkt 2 k.c.) co do zasady nie wywoła skutku w postaci utraty prawa żądania obniżenia kary konwencjonalnej ${ }^{39}$.

Ostatni z wątków dotyczących istoty jurydycznej miarkowania kary umownej dotyczy terminu, w którym owo uprawnienie można wykonać. Brak tu materialnoprawnych podstaw uzasadniających przekonanie, że uprawnienie dłużnika do żądania redukcji kary umownej jest ograniczone terminem prekluzyjnym. Zgłoszenie wywiedzionego $\mathrm{z}$ art. $484 \$$ 2 k.c. zarzutu możliwe jest w zasadzie do dnia zakończenia postępowania drugoinstancyjnego przed sądem (art. 316 k.p.c. w zw. z art. $391 \$ 1$ k.p.c.) ${ }^{40}$. Jedyne granice w omawianym zakresie mogą nakreślać właściwe przepisy prawa procesowego, w szczególności dotyczące pominięcia przez sąd spóźnionych twierdzeń i dowodów na etapie udzielania odpowiedzi na pozew, z wyjątkiem uprawdopodobnienia przez stronę niezgłoszenia ich w piśmie procesowym bez swojej winy (art. $207 \$ 6$ k.p.c.), jak i pominięcia spóźnionych twierdzeń i dowodów w celu uniknięcia zwłoki w rozpoznaniu sprawy albo z uwagi na inne wyjątkowe okoliczności (art. $217 \$ 2$ k.p.c.). Podzielić należy ponadto pogląd, że sędziowskie prawo redukcji kary względem uczestników obrotu profesjonalnego

38 Takie stanowisko prezentują P. Drapała, A. Olejniczak, Dodatkowe zastrzeżenia..., s. 1160.

39 Zob. W. Borysiak, Komentarz do art. 484 (w:) K. Osajda (red.), Komentarz..., nb. 35; P. Drapała, A. Olejniczak, Dodatkowe zastrzeżenia..., s. 1160 .

40 Zob. W. Popiołek, Komentarz... (w:) K. Pietrzykowski (red.), Kodeks cywilny..., nb. 12. 


\section{Instrument miarkowania kary umownej nie powinien}

\section{być per analogiam odnoszony do tych zobowiązań,}

\section{którym nie można przypisać charakteru kary umownej}

winno być wykonywane ze szczególną ostrożnością. Od podmiotów stale partycypujących w obrocie gospodarczym należy wymagać zdecydowanie większej staranności i zdolności poprawnej oceny ryzyka w związku z konsensem co do związania się określonymi postanowieniami umownymi aniżeli w stosunku do podmiotów nieuczestniczących w sposób profesjonalny w obrocie ${ }^{41}$. Instrument miarkowania kary umownej nie powinien być jednak per analogiam odnoszony do tych zobowiązań, którym nie można przypisać charakteru kary umownej ${ }^{42}$.

\subsection{Przesłanki miarkowania}

Aby można było mówić o zastosowaniu instrumentu miarkowania, konieczne jest wystąpienie co najmniej jednej z dwóch przesłanek, które ustawodawca expressis verbis wymienił $\mathrm{w}$ art. $484 \$ 2 \mathrm{k} . c .$, powiadając, że dłużnik może żądać zmniejszenia kary umownej, jeżeli 1) zobowiązanie zostało w znacznej części wykonane, lub wówczas, gdy 2) kara umowna jest rażąco wygórowana. $\mathrm{Z}$ uwagi na nacisk prawodawcy na urzeczywistnianie zasady realnego wykonania zobowiązań, której miarkowanie jest jednym z ograniczeń, przekonywające jest założenie, że przesłanki uzasadniające miarkowanie winny być traktowane jako wyliczenie taksatywne ${ }^{43}$, zaś obie względem siebie mają charakter równorzędny i rozłączny ${ }^{44}$. W doktrynie ${ }^{45}$ i judykatu-

41 Podobnie P. Drapała, A. Olejniczak, Dodatkowe zastrzeżenia..., s. 1161; zdaje się także W. Popiołek, Komentarz... (w:) K. Pietrzykowski (red.), Kodeks cywilny..., nb. 10.

42 Zob. W.W. Popiołek, Komentarz... (w:) K. Pietrzykowski (red.), Kodeks cywilny..., nb. 10 oraz cyt. tam autorzy.

43 Tak też J. Szwaja, Kara umowna..., s. 138.

44 Zob. P. Drapała, A. Olejniczak, Dodatkowe zastrzeżenia..., s. 1161 .

45 Za takim stanowiskiem opowiada się T. Wiśniewski, Komentarz do art. 484 (w:) J. Gudowski (red.), Kodeks cywilny..., nb. 6 LEX, przyjmując, że „katalog kryteriów pozwalających rze $^{46}$ pojawia się także stanowisko odmienne, przyjmujące otwarty katalog przesłanek z art. $484 \$ 2$ k.c., jednak różnica poglądów w tej kwestii ma w istocie niewielkie znaczenie praktyczne z uwagi na szeroką modalność przesłanki „rażącego wygórowania” ${ }^{37}$.

\subsection{Przestanka wykonania zobowiązania w znacznej części}

Mimo że przesłanka ta nie została verba legis zdefiniowania, to określenie jej normatywnego zakresu i granic zostało w zasadzie poczynione przed doktrynę. I tak - w pierwszej kolejności uwagę zwraca zamierzenie niedookreślone sformułowanie „znacznej części”, które odnosi się do „poziomu wykonania” zobowiązania. W każdym przypadku ujęcie wykonania ciążącego na dłużniku obowiązku w stopniu znacznym będzie rozumiane inaczej, w relacji do całości włożonego na niego zobowiązania, a tym samym w odniesieniu do pewnego obiektywnego wzorca należytej staranności (konstruowanego np. ex art. 354 k.c.). Jest to zasadnicza różnica pomiędzy omawianą tu przesłanką

na zmniejszenie kary umownej nie jest zamknięty", co wywodzi z uzasadnienia przywoływanej już kilkakrotnie uchwały SN (7) z dnia 6 listopada 2003 r. - zasady prawnej, sygn. akt III CZP 61/03, OSNC 2004, nr 5, poz. 69, z glosami W. Borysiaka, MP 2007, nr 6, s. 325; M. Bieniaka, MP 2005, nr 20, s. 1010; A. Slisza, MP 2005, nr 8, s. 406; J. Jastrzębskiego, OSP 2004, z. 9, poz. 115, oraz z omówieniem Z. Strusa, Przegląd orzecznictwa, „Palestra” 2004, nr 1-2, s. 215. Podobnie także W. Borysiak, Funkcje kary umownej..., s. 46.

46 Zob. w szczególności wielokrotnie powoływana uchwała SN (7) z 06.11.2003 r., sygn. akt III CZP 61/03, OSNC 2004, nr 5, poz. 69; a także wyrok SN z 05.10.2011 r., sygn. akt IV CSK 659/10, Legalis; wyrok SN z 12.02.2015 r., sygn. akt IV CSK 276/14, Legalis.

47 Podobnie W. Borysiak, Komentarz do art. 484 (w:) K. Osajda (red.), Kodeks cywilny..., nb. 37 in fine. 
a drugą z nich, dotyczącą rażącego wygórowania kary, bowiem w przypadku tej ostatniej ustawodawca nie odwołał się do żadnego obiektywnego punktu oceny wysokości zastrzeżenia ${ }^{48}$. Co więcej, wykonanie zobowiązania w znacznej części oceniane jest zarówno przed powstaniem, jak i po powstaniu obowiązku zapłaty kary umownej ${ }^{49}$, zaś miarodajnym punktem oceny znaczności wykonania zobowiązania jest rzeczywisty stopień zaspokojenia interesu wierzyciela w części zbliżającej się do pełnego jego zaspokojenia ${ }^{50}$. Interes ten winien być obiektywnie godny ochrony $^{51}$, bowiem możliwe są sytuacje, kiedy mimo faktycznego spełnienia przez dłużnika świadczenia $\mathrm{w}$ istotnej części, interes wierzyciela w dalszym ciągu nie jest zaspokojony ${ }^{52}$.

\subsection{Przestanka kary umownej rażąco wygórowanej}

Jak już na początku zauważono, ustawodawca przewidział zastrzeżenie umowne zastrzegające karę wadialną nazbyt wysoką, wobec czego z uwagi także i na tę okoliczność dopuścił prawo redukcji kary umownej. Przez wzgląd na rozłączne traktowanie obu przesłanek i ich równorzędną pozycję mogą one pozostawać ze sobą w zbiegu, co zdaje się w jeszcze większym

48 Zob. P. Drapała, A. Olejniczak, Dodatkowe zastrzeżenia..., s. 1161.

49 Tak W. Popiołek, Komentarz... (w:) K. Pietrzykowski (red.), Kodeks cywilny..., nb. 7.

50 Zob. W. Borysiak, Komentarz do art. 484 (w:) K. Osajda (red.), Komentarz..., nb. 40.

51 Por. J. Szwaja, Kara umowna..., s. 146; J. Jastrzębski, Kara umowna, s. 332.

52 Tak P. Drapała, A. Olejniczak, Dodatkowe zastrzeżenia..., s. 1161. W sprawie oceny poziomu „znaczności” wykonania zobowiązania w kontekście uwzględnienia kryterium przy datności przedmiotu świadczenia dla wierzyciela, a także w relacji do wspomnianego już obowiązku współdziałania przy wykonaniu zobowiązania zob. szerzej Z. Gawlik, Komentarz..., nb. 8-10; W. Popiołek, Komentarz... (w:) K. Pietrzykowski (red.), Kodeks cywilny..., nb. 7. Z kolei szerzej negatywnie o zasadności ustalania granicy, od której rozpoczyna się wykonanie zobowiązania „w znacznej części” w sposób sztywny, por. M. Lemkowski, Komentarz do art. 484 (w:) M. Gutowski (red.), Kodeks cywilny..., nb. 7. stopniu przesądzać o konieczności dokonania redukcji zastrzeżonej kary ${ }^{53}$.

Najwięcej wątpliwości powoduje jednak ustalenie sui generis katalogu kryteriów, względem których należałoby odnosić zarzut rażącego wygórowania kary i dokonywać właściwej oceny. Z uwagi na postępującą współcześnie dywersyfikację stosunków gospodarczych nie byłoby uzasadnione odwoływanie się wyłącznie do jednego wyselekcjonowanego elementu, stanowiącego ograniczony wzorzec kontroli, z pominięciem konieczności dokonywania wieloaspektowej oceny wygórowania kary wadialnej, uwzględniając przy tym szczególnie relewantne a casu okoliczności ${ }^{54}$. Nie jest więc pożądane - zdaniem części doktrynyodwoływanie się wyłącznie do jednego kryterium porównawczego, np. odszkodowania na zasadach ogólnych ${ }^{55} \mathrm{czy}_{\text {interesu wierzyciela }}{ }^{56}$. Zaznacza się, że wpływ na karę umowną będzie miał szeroki katalog okoliczności, w szczególności zaś rodzaj zobowiązania i jego znaczenie dla wierzyciela ${ }^{57}$. Analogicznie za kryterium może być uznana często dyskutowana w literaturze przesłanka szkody, a konkretniej - wielkości poniesionej szkody w stosunku do wysokości zastrzeżonej kary umownej, nieponiesienia tejże szkody przez wierzyciela w ogóle, jak też poniesienie jej, acz w niewielkim rozmiarze ${ }^{58}$.

Ustawodawca nie pozostawił przy tym żadnej dyrektywy interpretacyjnej, która pozwoliłaby na ustalenie znaczenia „rażącego wygórowania”, cedując in spe obowiązek wykładni tego pojęcia na doktrynę i orzecznictwo. Za wygórowaną w sposób rażący zasadnie uznano więc tę karę umowną, wobec której system prawny nie może pozostawać bierny co do dysproporcji pomiędzy jej wysokością a godnym ochrony

53 Tak też J. Jastrzębski, Kara umowna, s. 333.

54 Podobnie M. Lemkowski, Komentarz do art. 484 (w:) M. Gutowski (red.), Kodeks cywilny..., nb. 8.

55 Tak J. Szwaja, Kara umowna..., s. 144.

56 Takie stanowisko przyjmuje J. Jastrzębski, Kara umowna, s. 337 i n.

57 Zob. M. Lemkowski, Komentarz do art. 484 (w:) M. Gutowski (red.), Kodeks cywilny..., nb. 8.

58 Tak W. Popiołek, Komentarz... (w:) K. Pietrzykowski (red.), Kodeks cywilny..., nb. 8. 
interesem wierzyciela ${ }^{59}$. Nie oznacza to jednak, że ustalona w umowie wysokość stawki kary umownej przesądza każdorazowo o rażącym wygórowaniu ${ }^{60}$, bowiem oceny tej dokonywać należy z uwzględnieniem wszystkich okoliczności danego stosunku. Szczególnie aktualizuje się to w odniesieniu do możliwych dysproporcji pomiędzy stawkami przyjętymi dla obrotu profesjonalnego i poza nim.

Rozważania te pozwalają skonstatować, że w prawie polskim za karę umowną rażącą wygórowaną uznaje się zastrzeżenie, które w momencie dokonywania oceny jego niewspółmierności - a więc co do zasady $\mathrm{w}$ fazie zamknięcia rozprawy (art. $316 \S 1$ k.p.c.) ${ }^{61}$ przewyższa odszkodowanie, które mogłoby zostać przyznane wierzycielowi na zasadach ogólnych ${ }^{62}$. Sąd $\mathrm{z}$ kolei powinien mieć także na względzie podstawowe funkcje kary umownej, w szczególności zaś funkcję stymulacyjną co do wykonania zobowiązania, represyjną w kontekście należnej za niewykonanie lub nienależyte wykonanie zobowiązania sankcji, jak i kompensacyjną co do zaspokojenia uszczerbku w godnym ochrony interesie majątkowym wierzyciela ${ }^{63}$.

59 Zob. tamże; jak również P. Drapała, A. Olejniczak, Dodatkowe zastrzeżenia..., s. 1165-1166.

60 Tamże.

61 Zob. W. Borysiak, Komentarz do art. 484 (w:) K. Osajda (red.), Komentarz..., nb. 49. Co do innych momentów miarodajnych dla oceny wysokości kary umownej w kontekście przesłanki rażącego wygórowania zob. P. Drapała, A. Olejniczak, Dodatkowe zastrzeżenia..., s. 1164, gdzie przyjęto, że „sąd mógłby brać pod uwagę okoliczności z chwili zastrzegania kary umownej, z chwili spełnienia się przesłanek powstania roszczenia o karę umowną (tzw. zapadnięcia kary), z momentu wytoczenia przez wierzyciela powództwa o świadczenie kary oraz z chwili zamknięcia rozprawy (art. $316 \$ 1$ k.p.c.). Zważywszy, iż miarkowanie powinno opierać się na rozważeniu przez sąd całokształtu okoliczności niewykonania lub nienależytego wykonania zobowiązania, najbardziej trafny wydaje się wariant ostatni”.

62 Por. M. Lemkowski, Komentarz do art. 484 (w:) M. Gutowski (red.), Kodeks cywilny..., nb. 8.

63 Szerzej co do poszczególnych funkcji kary umownej zob. W. Popiołek, Komentarz... (w:) K. Pietrzykowski (red.), Kodeks cywilny..., nb. 8.

\subsection{Wysokość kary umownej a przyczynienie się} wierzyciela

Wiele kontrowersji w doktrynie ${ }^{64}$ i orzecznictwie $^{65}$ wywołuje możliwość obniżenia kary umownej w sytuacji przyczynienia się wierzyciela do niewykonania lub nienależytego wykonania zobowiązania przez

64 Za taką możliwością opowiadają się m.in. J. Jastrzębski w glosie do powoływanego już wyroku SN z dn. 08.07.2004, sygn. akt IV CK 522/03, PS 2007, nr 4, s. 131 i n.; J. Jastrzębski, Kara umowna, s. 315-322; M. Pyziak-Szafnicka, Kilka uwag..., s. 2488-2490; F. Zoll, Pojęcie niewykonania i nienależytego wykonania zobowiązania oraz kwalifikowane postaci naruszenia zobowiązania i ich skutki (w:) A. Olejniczak (red.), System prawa prywatnego. Prawo zobowiązań - część ogólna, t. 6, Warszawa 2018, s. 1184; W. Borysiak, Komentarz do art. 484 (w:) K. Osajda (red.), Komentarz..., nb. 82; W. Popiołek Komentarz... (w:) K. Pietrzykowski (red.), Kodeks cywilny..., nb. 9. Przeciwnie natomiast zob. J. Szwaja, Kara umowna..., s. 144; Z. Gawlik, Komentarz do art. 484 (w:) A. Kidyba (red.), Kodeks cywilny..., nb. 7; K. Zagrobelny, Komentarz do art. 484 (w:) E. Gniewek, P. Machnikowski (red.), Kodeks cywilny..., nb. 8; M. Lemkowski, Komentarz do art. 484 (w:) M. Gutowski (red.), Kodeks cywilny..., nb. 8; J. Dąbrowa, Glosa do wyr. SN z 23.01.1974, sygn. akt II CR 788/73, „Orzecznictwo Sądów Polskich i Komisji Arbitrażowych” 1975, nr 2, poz. 36, s. 71-74.

65 Za stosowaniem art. 362 k.c. do kary umownej w orzecznictwie opowiedział się SN w powoływanym już wyroku z 23.01.1974 r., sygn. akt II CR 788/73, OSPiKA 1975, nr 2, poz. 36; wyrok SN z 09.10.2003 r., sygn. akt V CK 319/02, Legalis; wyrok SN z 09.10.2003 r., sygn. akt I CK 137/02, w którym SN przyjął, że „art. 362 odnosi się do każdej odpowiedzialności odszkodowawczej. Jednak jego zastosowanie do kary umownej może nastąpić jedynie odpowiednio, bowiem wierzyciel żądając kary umownej z reguły nie wskazuje wysokości poniesionej szkody, a zatem brak wskazanego w art. 362 k.c. kryterium obniżenia kary"; podobnie SA w Szczecinie w wyroku z 08.05.2013 r., sygn. akt I ACA 72/13, Legalis. Odmiennie z kolei zob. wyrok SN z 13.06.2003 r., sygn. akt III CKN 50/01, Legalis; pow. już wyrok SN 08.07.2004 r., sygn. akt IV CK 522/03, OSNC 2005, nr 7-8, poz. 131, w SN wprost stwierdził, że „przepis art. 362 k.c. nie może stanowić samoistnej podstawy zmniejszenia kary umownej"; wyrok SN z 16.04.2010 r., sygn. akt IV CSK 494/09, Biul. SN 2010, nr 5, poz. 150; także pow. kilkakrotnie wyrok SN z 06.02.2008 r., sygn. akt II CSK 428/07, Legalis; podobnie SA w Białymstoku w wyroku z 12.07.2017 r., sygn. akt I ACa 131/17, Legalis. 
dłużnika. Zwolennicy pierwszego poglądu argumentują, że jeżeli doszło do przyczynienia się wierzyciela, to dłużnik nie może domagać się miarkowania kary umownej, ale jej obniżenia zgodnie z art. 362 k.c. ${ }^{66}$ Przedstawiciele odmiennego zapatrywania uznają, stopnia redukcji ${ }^{69}$, bowiem w przypadku stosowania art. 362 k.c. zmniejszenie odszkodowania należnego wierzycielowi nie wymaga szczególnej „aktywności procesowej" po stronie dłużnika, inaczej niż miarkowanie kary umownej w trybie art. $484 \$ 2$ k.c. $^{70}$

\section{Niewystąpienie szkody w znaczeniu cywilistycznym} nie stanowi negatywnej przesłanki powstania obowiązku zapłaty kary umownej, lecz powinno być elementem uwzględnianym na etapie miarkowania kary umownej, zwłaszcza przy
badaniu przesłanki rażącego jej wygórowania.

że przyczynienie się nie może stanowić samoistnej przesłanki miarkowania, bowiem instrument ten znajduje zastosowanie tylko wówczas, gdy spełnione zostają przesłanki z art. $484 \$ 2$ k.c., których katalog nie może zostać rozszerzony dyspozycją art. 362 k.c. ${ }^{67}$ $\mathrm{Z}$ kolei przedstawiciele trzeciej koncepcji argumentują, że nie tylko możliwe jest obniżenie kary umownej z uwagi na przyczynienie się wierzyciela, ale dopuścić należy zbieg obu podstaw redukcji - zarówno tych $\mathrm{z}$ art. $484 \S 2$ k.c., jak i z art. 362 k.c. - prowadzący do ich kumulatywnego stosowania ${ }^{68}$. W działaniu obu tych mechanizmów istnieje jednak poważna różnica co do możliwości działania przez sąd z urzędu i określenia

66 Zob. chociażby M. Pyziak-Szafnicka, Kilka uwag..., s. 24882490; F. Zoll, System..., s. 1184; W. Borysiak, Komentarz do art. 484 (w:) K. Osajda (red.), Komentarz..., nb. 82; W. Popiołek Komentarz... (w:) K. Pietrzykowski (red.), Kodeks cywilny..., nb. 9 .

67 Por. w szczególności Z. Gawlik, Komentarz do art. 484 (w:) A. Kidyba (red.), Kodeks cywilny..., nb. 7; K. Zagrobelny, Komentarz do art. 484 (w:) E. Gniewek, P. Machnikowski (red.), Kodeks cywilny..., nb. 8; M. Lemkowski, Komentarz do art. 484 (w:) M. Gutowski (red.), Kodeks cywilny..., nb. 8.

68 Tak J. Jastrzębski, Glosa do wyr. SN z dn. 08.07.2004, sygn. akt IV CK 522/03, „Przegląd Sądowy” 2007, nr 4, s. 139.
W orzecznictwie przedstawiono jednak pogląd, który wyklucza możliwość uznania przyczynienia się wierzyciela za odrębną podstawę redukcji kary, wskazując na konieczność uwzględnienia tego zachowania uprawnionego podmiotu w procesie miarkowania kary umownej w oparciu o art. $484 \$ 2$ k.c. ${ }^{71}$ Zauważono bowiem, że dyspozycja art. 362 k.c. dozwala wyłącznie na obniżenie odszkodowania sensu stricto (art. $361 \$ 2$ k.c.), którego wysokość pozostaje z ścisłym związku z faktycznie poniesioną przez wierzyciela szkodą. Z kolei - jak przyjęto - kara umowna nie jest tego rodzaju odszkodowaniem, bowiem jej wysokość ustalana jest przez strony ex ante i nie pozostaje co do zasady w bezpośrednim związku z wysokością szkody powstałej w majątku wierzyciela (art. $484 \S$

69 Zob. szerzej J. Jastrzębski, Glosa do wyr. SN z dn. 08.07.2004, s. $140-141$.

70 Tak W. Borysiak, Komentarz do art. 484, (w:) K. Osajda (red.), Komentarz..., nb. 85, oraz cyt. tam literatura.

71 Zob. powoływany już wyrok SN z 16.4.2010 r., sygn. akt IV CSK 494/09, OSN 2010, nr D, poz. 115; wyrok SN z 4.3.2008 r., sygn. akt IV CSK 457/07, Legalis; wyrok SN z 6.2.2008 r., sygn. akt II CSK 428/07, Legalis. Za stanowiskiem tym opowiedzieli się także P. Drapała i A. Olejniczak, Dodatkowe zastrzė̇enia..., s. 1163. 
1 zd. 1 k.c.) $)^{72}$. Uznano więc, że stopień przyczynienia się wierzyciela względem powstania lub zwiększenia zakresu szkody powinien wpływać na karę umowną jedynie w ramach przeprowadzonego na podstawie art. $484 \$ 2$ k.c. miarkowania, co pozwoli uniknąć naznaczonych uprzednio rozbieżności co do tego, że przyczynienie się wierzyciela sąd może uwzględniać $\mathrm{z}$ urzędu, a miarkowanie kary wyłącznie na wniosek ${ }^{73}$. Zasadna jest także teza, że przyczynienie się wierzyciela będzie okolicznością, która winna zostać każdorazowo uwzględniona przy rozstrzyganiu o rażącym wygórowaniu kary umownej ${ }^{74}$.

\section{Instytucja miarkowania w modelowym prawie umów}

Podobnie jak w prawie polskim, również w prawie modelowym przewidziane zostały mechanizmy umożliwiające reakcję organu stosującego prawo na karę umowną rażąco wygórowaną lub niewspółmierną względem wykonanej przez dłużnika znacznej części zobowiązania. Już na początku warto jednak nadmienić, że żaden $\mathrm{z}$ analizowanych tu aktów prawa modelowego nie posługuje się wprost pojęciem „kary umownej”, używając właściwych sobie odpowiedników terminologicznych $^{75}$. Pominięte zostaną także rozważania co do szczegółów konstrukcyjnych kary umownej w prawie modelowym z uwagi na ich uprzednie omówienie ${ }^{76}$.

72 Tak P. Drapała, A. Olejniczak, Dodatkowe zastrzeżenia..., s. 1163.

73 Tamże, s. 1164.

74 Tak W. Popiołek, Komentarz... (w:) K. Pietrzykowski (red.), Kodeks cywilny..., nb. 11 in fine.

75 Tak też: „agreed payment for non-performance” w UPICC; „agreed payment for non-performance” w PECL; „stipulated payment for non-performance" w DCFR.

76 Zob. P. Widerski, Charakter prawny kary umownej wedtug prawa polskiego na tle ponadnarodowych uregulowań prawnych, „Studia Prawa Prywatnego” 2018, nr 2, s. 12 i n.; A.M. Juranek, Kara umowna, wybrane klauzule quasipenalne oraz klauzule indemnifikacyjne $w$ prawie polskim i prawie modelowym. Rozważania de lege lata $i$ de lege ferenda, Katowice 2019, s. 39 i n; A.M. Juranek, Międzynarodowa harmonizacja prawa prywatnego na przykładzie wybranych aktów modelowego prawa umów w zakresie regulacji kary umownej, „Zeszyty Prawnicze Biura Analiz Sejmowych Kancelarii Sejmu” 2020, nr 1(62), s. 30-53.
Szczegółową analizę warto rozpocząć od przypomnienia, że celem model law jest zapewnienie swoistego standardu regulacyjnego rozumianego jako pożądany poziom ochrony, który zapewni - w ramach procesu harmonizacji prawa prywatnego - jednolitość przyjętych przez organy poszczególnych państw rozwiązań w danej materii ${ }^{77}$. I tak w art. 7.4.13 ust. 2 chronologicznie pierwszego UPICC wprost przewidziano, że agreed sum may be reduced ${ }^{78}$. Wysokość odszkodowania umownego, niezależnie od odmiennych postanowień umowy, może zawsze ulec rozsądnemu zmniejszeniu, o ile tylko jest ona oczywiście wygórowana $\mathrm{z}$ uwagi na rzeczywiście poniesioną szkodę w wyniku niewykonania zobowiązania, a także z uwagi na inne okoliczności ${ }^{79}$. Redukcja kary umownej jako grossly excessive powinna nastąpić więc zawsze z uwzględnieniem relacji pomiędzy wysokością kary wadialnej a szkodą i innymi skutkami niewykonania lub nienależytego wykonania zobowiązania ${ }^{80}$. Stanowi to dodatkowy argument dla coraz powszechniejszego w polskiej doktrynie stanowiska, że „szkoda” rozumiana jako damnum emergens lub lucrum cessans nie powinna stanowić negatywnej przesłanki powstania roszczenia o karę umowną, ale mieć charakter relewantnego wskaźnika uwzględnianego w procesie jej miarkowania ${ }^{81}$, mimo że samo rażące wygórowanie kary umownej nie zostało przez polskiego ustawodawcę powiązane z wysokością szkody. Okoliczność

77 Szerzej na ten temat zob. A. Brzozowski, Wplyw zmiany okoliczności na zobowiązania w konwencji wiedeńskiej, prawie modelowym oraz praktyce międzynarodowego obrotu gospodarczego (w:) A. Olejniczak (red.), System..., s. 1363-1364; J. Poczobut, Źródła prawa kolizyjnego dla umowy o arbitraż (w:) A. Szumański (red.), System prawa handlowego. Arbitraż handlowy, t. 8, Warszawa 2015, s. $190 \mathrm{i} \mathrm{n}$.

78 Zob. Reguły UNIDROIT 2016, s. 340.

79 Przepis art. 7.4.13 ust. 2 Reguł UNIDROIT powiada bowiem, że „However, notwithstanding any agreement to the contrary the specified sum may be reduced to a reasonable amount where it is grossly excessive in relations to the harm resulting from the non-performance and to the other curcumstances".

80 Zob. Reguły UNIDROIT 2016, s. 340.

81 Zob. szerzej na ten temat charakteru szkody w przywoływanej już pracy W. Popiołka, Komentarz do art. 483 (w:) K. Pietrzykowski (red.), Kodeks cywilny..., oraz cyt. tam literaturę. 
ta stanowi przemożną odmienność w porównaniu do reguł prawa modelowego, gdzie szkodę wprost nakazuje się uwzględniać przy stosowaniu instrumentu redukcji ${ }^{82}$. Wymaga zauważenia, że przepisy traktujące o miarkowaniu kary umownej w UPICC zostały określone jako skuteczne despite any provision to the contrary, co przesądza o ich kogentnym charakterze ${ }^{83}$.

Podobnie także w europejskich aktach prawa modelowego ${ }^{84}$ konstrukcja miarkowania kary umownej została stosunkowo zbliżona do Reguł UNIDROIT. Zgodnie bowiem z treścią art. 9:509 pkt 2 PECL $^{85}$ - bez względu na przeciwne postanowienia stron wysokość odszkodowania umownego może być obniżona do rozsądnej wysokości, jeżeli jest ona nadmiernie wygórowana, $\mathrm{z}$ uwagi na straty wynikające $\mathrm{z}$ niewykonania zobowiązania lub inne okoliczności. Sformułowanie w ten sposób instrumentarium służącego miarkowaniu prowadzi więc do kilku relewantnych wniosków. Po pierwsze - mamy do czynienia z normami o charakterze bezwzględnie obowiązującym, co jest w zasadzie powieleniem założenia przyjętego $\mathrm{w}$ art. 7.4 .13 ust. 2 UPICC. Pozwala to na podzielenie pojawiającego się w polskim piśmiennictwie poglądu o bezwzględnej nieważności klauzul wyłączających miarkowanie lub ograniczających jego zastosowanie in minori. Co ciekawe, założeniem model law jest zapewnienie stronom możliwie szerokiej modalności postanowień występujących w łączącym je stosunku. Jednak wskazanie, że strony mogą agreed payment między sobą redukować - i to niezależnie od przeciwnych postanowień gwarantuje owo prawo redukcji w sposób niebudzący wątpliwości, ograniczając zasadę in conventionibus contrahentium. Można więc poczytywać to także za argument w dyskursie o dopuszczalności zrzeczenia się przez dłużnika żądania miarkowania kary umow-

82 Tak też P. Widerski, Charakter prawny..., s. 21.

83 Podobnie P. Drapała, A. Olejniczak, Dodatkowe zastrzeże nia..., s. 1135.

84 Przez europejskie prawo modelowe należy tutaj rozumieć Zasady PECL i DCFR; UPICC traktowane są jako regulacja o charakterze globalnym.

85 Art. 9:509 ust. 2 PECL powiada, że „However, despite any agreement to the contrary the specified sum may be reduced to a reasonable amount where it is grossly excessive in relation to the loss resulting from the non-performance and the other circumstances". nej (vel zarzutu rażącego jej wygórowania), przesądzający o bezwzględnym wpływie instrumentarium miarkowania na komentowane zastrzeżenie, choćby nawet wola stron była odmienna. Po drugie, granicą gradacji w procesie miarkowania jest klauzula reasonable amount („rozsądnej wysokości”). Pozwala to na wyprowadzenie charakterystycznej dla części polskiej doktryny i orzecznictwa konstatacji ${ }^{86}$, że na skutek zastosowania instrumentu miarkowania kary umownej nie może dojść do sytuacji, w której dłużnik zostałby całkowicie zwolniony z obowiązku jej świadczenia. Tym samym zapatrywania doktryny powielające tę tezę wydają się bardziej przekonywające, aniżeli stanowiska odmienne, dopuszczające w określonych przypadkach możliwość miarkowania „do zera”87.

Po trzecie, Zasady PECL w żaden sposób nie odnoszą się expressis verbis do redukcji kary umownej w sytuacji wykonania zobowiązania przez dłużnika w znacznej mierze. Zawarta jednak w art. 9:509 ust. 2 in fine PECL klauzula other circumstances („innych okoliczności”) zdaje się dozwalać na szerokie wykładanie tej przesłanki w stopniu, który zarówno obejmuje wynikające z art. $484 \$ 2$ k.c. wykonanie zobowiązania przez dłużnika w znacznej części, jak i dopuszcza uwzględnienie innych relewantnych a casu okoliczności, chociażby komentowanego uprzednio przyczynienia się wierzyciela do niewykonania lub nienależytego wykonania zobowiązania. Po czwarte, brak jest definicji „rażącego wygórowania” kary umownej w prawie modelowym, co nie jest zjawiskiem obcym również w polskim porządku prawnym. Niemniej trudno zakładać, że twórcy Reguł UPICC czy Zasad PECL nie zdawali sobie sprawy z takiej konieczności. Należałoby przy-

86 Tak m.in. W. Popiołek, Komentarz... (w:) K. Pietrzykowski (red.), Kodeks cywilny..., nb. 10; P. Drapała, A. Olejniczak, Dodatkowe zastrzeżenia..., s. 1166; oraz kilkakrotnie powoływany wyrok SN z 04.12.2003 r., sygn. akt II CK 271/02; por. także wyrok SA w Katowicach z 12.01.2017 r., sygn. akt V ACa 492/16, POSP; wyrok SA w Białymstoku z 22.12.2016 r., sygn. akt I ACa 591/16, POSP; wyrok SA w Katowicach z 28.06.2001 r., sygn. akt I ACa 295/01, PG 2002, nr 10.

87 Powoływany już W. Borysiak, Funkcje kary umownej..., s. 53; M. Pyziak-Szafnicka, Kilka uwag na temat... (w:) J. Gudowski, K. Weitz (red.), Aurea praxis..., s. 2251. A także orzecznictwo - zob. wyrok SA w Szczecinie z 11.10.2012 r., sygn. akt I ACa 518/12 Legalis. 
jąć proporcjonalnie odwrotnie, uznając, że pojęcie to powinno być definiowane w sposób elastyczny, właściwy dla każdego przypadku zastosowania tej regulacji, z uwzględnieniem przesłanek określonych tak prawem modelowym, jak i krajowym. Po piąte, ani w Regułach UPICC, ani w zasadach PECL nie odniesiono się do kwestii dopuszczalności miarkowania uzgodnionej płatności w stosunku do „szkody wynikającej" (harm resulting) poniesionej przez wierzyciela, jak również 2) klauzulę „innych okoliczności” (other circumstances). Mimo względnie zbieżnego rozumienia pierwszej z przesłanek w prawie polskim i modelowym nie budzi zastrzeżeń zdecydowanie szersze określenie w model law drugiego kryterium. Przyjąć

\section{Przesłankę „wykonania zobowiązania w znacznej części” należy ocenić jako nader kazuistyczną} i archaiczną, $\mathrm{w}$ porównaniu $\mathrm{z}$ proponowaną $\mathrm{w}$ prawie modelowym przesłanką „innych okoliczności”.

wyłącznie „już należnej” wierzycielowi kary umownej, co może stanowić argument za stanowiskiem pośrednim, nakazującym rozpatrywanie tej kwestii a casu, w razie konieczności więc także z odwołaniem się do powszechnie uznawalnych zasad prawa umów. Można wszak wyobrazić sobie sytuację, w której w określonym stanie faktycznym strony uczciwie i w pełni szczerze zmierzały do wykonania łączącego je zobowiązania, do którego ostatecznie z różnych względów nie doszło, jak również sytuację, w której jedna $\mathrm{z}$ kontraktujących stron $a b$ initio nie dochowywała należytej staranności lub w określonej fazie trwania stosunku podjęła czynności, które nie czyniły zadość istniejącemu między nimi obowiązkowi lojalności. Tym samym zasadność stosowania miarkowania kary umownej w uzależnieniu od wymagalności lub niewymagalności roszczenia mogłaby zostać każdorazowo rozpatrzona przez organ stosujący prawo, o ile zabieg ten czyniłby zadość zasadom słuszności czy szeroko rozumianemu lex mercatoria. Jest to jednak kwestia z pewnością kontrowersyjna. Po szóste, we wszystkich trzech rozważanych aktach w sposób nieco odmienny aniżeli w prawie polskim ujęto przesłanki miarkowania kary umownej. Kodeks cywilny posługuje się bowiem 1) wykonaniem zobowiązania w znacznej mierze lub 2) rażącym wygórowaniem kary. Z kolei Reguły UNIDROIT wskazują na 1) rażącą wysokość należy, że nakazuje ono uwzględnienie wszelkich dodatkowych okoliczności mogących mieć znaczenie dla zastosowania miarkowania, a nie wyłącznie wykonanie zobowiązania w znacznym stopniu, jak przyjęto w art. $484 \$ 2$ k.c. Warto zasygnalizować także pewną odmienność terminologiczną w kontekście pierwszej przesłanki UPICC (harm resulting) i jej odpowiedników w Zasadach PECL i DCFR (loss resulting). Różnica w omawianych aktach polega na posłużeniu się przez twórców PECL i DCFR ${ }^{88}$ terminem „straty wynikającej” jako jednego z kryteriów uwzględnianych w procesie miarkowania kary umownej, a nie znanej z UPICC „szkody wynikającej”. Mimo w zasadzie semantycznej zbieżności w języku potocznym pomiędzy oboma sformułowaniami z perspektywy nawiązania do określonego w systemie prawa prywatnego rozumienia terminu „szkody” posługiwanie się właśnie tym pojęciem należałoby uznać za bardziej uzasadnione. Co prawda polskie prawo prywatne posługuje się również pojęciem „straty”, jednak dla oznaczenia zgoła odmiennych okoliczności aniżeli rozważane

88 Art. III-3:712 ust. 2 stanowi, że „however, despite any provision to the contrary, the sum so specified in a contract or other juridical act may be reduced to a reasonable amount where it is grossly excessive in relation to the loss resulting from the non-performance and the other circumstances". 
kryterium miarkowania ${ }^{89}$. Ostatnia, siódma uwaga dotyczy braku wskazania przez twórców model law terminu, w którym dłużnik miałby wykonać przysługujące mu uprawnienie żądania miarkowania. Nie powinno to zaskakiwać, bowiem jak wspomniano - intencją prawa modelowego jest uczynienie mechanizmów obowiązujących w poszczególnych systemach prawa krajowego możliwie elastycznymi, modalnymi. Model law ma stanowić „propozycję syntezy dorobku europejskiej doktryny prawa kontraktowego" 90 . Stąd oktrojowanie jakkolwiek - nawet dogłębnie - „rozważonych" terminów stanowiłoby wyłom w tej intencji. Niemniej - mając na względzie samą istotę prawa modelowego - analiza komparatystyczna przeprowadzona przez organy sięgające do model law w zakresie rozwiązań najczęściej preferowanych w systemach państw UE mogłaby doprowadzić do ustalenia możliwie pożądanego i racjonalnego terminu.

Podobnie jak Zasady PECL, również system DCFR przewiduje instrument miarkowania kary umownej ${ }^{91}$. Zgodnie z treścią art. III-3:712 ust. 2 DCFR, bez względu na przeciwne postanowienia stron, wysokość odszkodowania określona w umowie lub innej czynności prawnej może być obniżona do rozsądnej wysokości, jeżeli jest ona nadmiernie wygórowana, z uwagi na szkodę wynikłą z niewykonania lub inne okoliczności. Ze względu na okoliczność, że regulacja Draftu w zakresie stiupalted payment stanowi w zasa-

89 Co do różnic w tym zakresie zob. w szczególności wyrok SN z 11.07.1957 r., sygn. akt II CR 304/57, LexPolonica nr 316158, OSN 1958, nr III, poz. 76; uchwała SN (7) z 22.11.1963 r., sygn. akt III PO 31/63, LexPolonica nr 315214, OSNCP 1964, nr 7-8, poz. 128. Moim zdaniem szkoda jest - egzemplifikując - powstałą wbrew woli poszkodowanego różnicą między obecnym jego stanem majątkowym a tym stanem, jaki zaistniałby, gdyby nie nastąpiło zdarzenie wywołujące szkodę. Jeżeli chodzi o definicję straty, to jest nią pomniejszenie majątku poszkodowanego. Polega ona, w maksymalnym uproszczeniu, na uszczupleniu aktywów (np. zniszczenie, utrata lub uszkodzenie określonych składników majątkowych albo obniżenie ich wartości) albo na przybyciu pasywów (np. powstanie nowych zobowiązań albo ich zwiększenie); por. szerzej także A. Sinkiewicz, Pojęcie i rodzaje szkody w polskim prawie cywilnym, „Rejent” 1998, nr 2(82), s. 59-74.

90 Tak A. Brzozowski, Wplyw zmiany..., s. 1363.

91 Zob. także P. Widerski, Charakter prawny..., s. 15. dzie powtórzenie konstrukcji przyjętej w PECL-u, nie została ona odrębnie omówiona.

\section{Wnioski}

W następstwie przeprowadzonych w ramach niniejszego opracowania rozważań ustalono, że instrument miarkowania kary umownej jest charakterystyczny nie wyłącznie polskiemu systemowi prawa, ale występuje również w najnowocześniejszych projektach ponadnarodowej harmonizacji prawa prywatnego. I tak w pierwszej kolejności należy pozytywnie ocenić całość konstrukcji miarkowania, która wynika z art. $484 \$ 2$ k.c. Z uwagi bowiem na fakt, że w k.c. pozostaje ona w niezmienionym kształcie od 1964 r., a w formie odrobinie zmodyfikowanej funkcjonowała także w Kodeksie zobowiązań z 1933 r., i w obu tych przypadkach odpowiada w zasadniczej mierze nowoczesnym tendencjom legislacyjnym - należy zdecydowanie docenić technikę legislacyjną polskiego prawodawcy. Mimo jednak zasadniczej zbieżności z nowoczesnym „trendem” legislacyjnym - polska konstrukcja cechuje się sui generis archaicznym powiązaniem powstania szkody w majątku wierzyciela ze zmaterializowaniem się roszczenia o zapłatę kary umownej. Co prawda wysłowiona verba legis przesłanka odpowiedzialności za szkodę jest coraz częściej presuponowana przez doktrynę do uwzględnienia dopiero na etapie stosowania instrumentu miarkowania, niemniej w dalszym ciągu stanowiska nie są w tej mierze spójne, zaś sama dyspozycja art. $484 \$ 1$ k.c. wiąże się z „naprawieniem szkody wynikłej z niewykonania..." (art. $483 \$ 1$ k.c.), acz bez względu na jej wysokość (art. $484 \$ 1$ zd. 1 k.c.). W dalszej kolejności zwraca również uwagę archaiczność drugiej przesłanki miarkowania z art. $484 \$ 2$ k.c., tzn. wykonania przez dłużnika zobowiązania „w znacznej części”. Twórcy prawa modelowego nie wiążą zasadności zastosowania miarkowania wyłącznie z okolicznością wykonania już w jakieś części zobowiązania, ale wskazują na zdecydowanie szerszą w kontekście możliwych desygnatów klauzulę other circumstances. Bez wątpienia jej wprowadzenie lepiej oddaje istotę dyskrecjonalnej władzy sędziowskiej (wszak sędzia z uwzględnieniem rozlicznych okoliczności może, acz nie musi sięgnąć do miarkowania) aniżeli zamknięcie ewentualnej drogi na wszystkie zdarzenia, które nie są funkcjonalnie związane z wykonaniem zobowiązania 
„W znacznej części”. Tym samym posłużenie się przywołaną klauzulą „innych okoliczności” zamknęłoby trwającą w polskim piśmiennictwie dyskusję w kontekście uwzględnienia ewentualnego przyczynienia się wierzyciela do powstania szkody przy jej miarkowaniu, nakazując uwzględnienie organowi stosującemu wszelkich relewantnych dla sprawy okoliczności.

$\mathrm{W}$ pozostałym zakresie przyjęta $\mathrm{w}$ art. $484 \$ 2$ k.c. konstrukcja miarkowania kary umownej jest w zasadzie albo zbieżna z nowoczesnymi ponadnarodowymi projektami kodyfikacyjnymi, albo interpretowana przez opinio communis doctorum w sposób zmierzający do zrównania z nowoczesnymi nurtami legislacyjnymi i urzeczywistnienia procesu europejskiej harmonizacji prawa prywatnego. Nie zwalnia to jednak ustawodawcy krajowego $\mathrm{z}$ analizowania rozwiązań przyjętych chociażby w omawianym tu model law z uwagi m.in. na konieczność odpowiedniego dostosowania przepisów krajowych do postępującej dywersyfikacji obrotu gospodarczego w oparciu o mocną bazę komparatystyczną, jak też normatywnego rozstrzygnięcia dylematów, które stanowią przedmiot licznych kontrowersji zarówno w doktrynie, jak i w orzecznictwie.

\section{Bibliografia}

Borysiak W., Funkcje kary umownej w świetle uchwały składu siedmiu sędziów Sądu Najwyższego z 6 listopada 2003 r. (III CZP 61/03), „Palestra” 2006, nr 7-8, s. 46-56.

Borysiak W., Komentarz do art. 484 (w:) K. Osajda (red.), Kodeks cywilny. Komentarz. Zobowiązania. Część ogólna, t. IIIA, Warszawa [C.H. Beck] 2017.

Brzozowski A., Wpływ zmiany okoliczności na zobowiązania $w$ konwencji wiedeńskiej, prawie modelowym oraz praktyce międzynarodowego obrotu gospodarczego (w:) A. Olejniczak (red.), System prawa prywatnego. Prawo zobowiązań - część ogólna, t. 6, Warszawa [C.H. Beck] 2018.

Canaris W., Verfassungs- und europarechtliche Aspekte der Vertragsfreiheit (w:) Wege und Verfahren des Verfassungslebens. Festschrift für Peter Lerche zum 65. Geburtstag, München [C.H. Beck] 1993.

Dąbrowa J. (w:) Z. Radwański, System prawa cywilnego, t. 3, cz. 1: Prawo zobowiązań - część ogólna, Warszawa [C.H. Beck] 1981.

Domański L., Instytucje kodeksu zobowiązań. Komentarz teoretyczno-praktyczny. Część ogólna, t. 2, Warszawa [Marjan Ginter - Księgarnia Wydawnictw Prawniczych] 1936.
Drapała P., Glosa do wyroku SN z 23 marca 2006 r., sygn. akt IV CSK 89/05, „Przegląd Sądowy” 2007, nr 5, s. 122 i n.

Drapała P., Olejniczak A., Dodatkowe zastrzeżenia umowne (w:) E. Łętowska (red.), System prawa prywatnego. Prawo zobowiazań - część ogólna, t. 5, Warszawa [C.H. Beck] 2013.

Gawlik Z., Komentarz do art. 484 (w:) A. Kidyba (red.), Kodeks cywilny. Komentarz. Zobowiązania. Część ogólna, t. 3, Warszawa [C.H. Beck] 2014.

Gniewek E., Machnikowski P. (red.), Kodeks cywilny. Komentarz, Warszawa [C.H. Beck] 2017.

Gudowski J. (red.), Kodeks cywilny. Komentarz, t. 3: Zobowiązania. Część ogólna, Warszawa [C.H. Beck] 2017.

Gudowski J., Weitz K. (red.), Aurea praxis. Aurea theoria. Księga pamiątkowa ku czci Profesora Tadeusza Erecińskiego, t. 2, Warszawa [LexisNexis] 2011.

Gutowski M. (red.), Kodeks cywilny, t. 2: Komentarz do art. 353626, Warszawa [C.H. Beck] 2019.

Jastrzębski J., Glosa do uchw. SN (7) z 06.11.2003 r., sygn. akt III CZP 61/03, „Orzecznictwo Sądów Polskich” 2004, nr 9, poz. 115, s. 492 i n.

Jastrzębski J., Glosa do wyr. SN z dn. 08.07.2004, sygn. akt IV CK 522/03, „Przegląd Sądowy” 2007, nr 4, s. 131 i n.

Jastrzębski J., Kara umowna, Kraków [Wolters Kluwer] 2006. Juranek A.M., Kara umowna, wybrane klauzule quasipenalne oraz klauzule indemnifikacyjne w prawie polskim i prawie modelowym. Rozważania de lege lata $i$ de lege ferenda, Katowice [Instytut Nauk Prawnych Uniwersytetu Śląskiego w Katowicach] 2019. Juranek A.M., Międzynarodowa harmonizacja prawa prywatnego na przykładzie wybranych aktów modelowego prawa umów w zakresie regulacji kary umownej, „Zeszyty Prawnicze Biura Analiz Sejmowych Kancelarii Sejmu” 2020, nr 1(62), s. 30-53. Kidyba A. (red.), Kodeks cywilny. Komentarz. Zobowiązania. Część ogólna, t. 3, Warszawa [C.H. Beck] 2014.

Korzan K., Orzeczenia konstytutywne w postępowaniu cywilnym, Warszawa [Wydawnictwo Prawnicze] 1972.

Lemkowski M., Komentarz do art. 484 (w:) M. Gutowski (red.), Kodeks cywilny, t. 2: Komentarz do art. 353-626, Warszawa [C.H. Beck] 2019.

Lindacher K., Phänomenologie der Vertragsstrafe. Vertragsstrafe, Schadensersatzpauschalierung und schlichter Schadensbeweisvertrag, Würzburg [Athenaeum Verlag] 1972.

Longchamps de Bérier R., Uzasadnienie projektu kodeksu zobowiązań z uwzględnieniem ostatecznego tekstu kodeksu, Warszawa [Wydawnictwo Urzędowe Komisji Kodyfikacyjnej] 1935.

Longchamps de Bérier R., Zobowiązania, Poznań [Księgarnia Akademicka] 1948. 
Łętowska E. (red.), System prawa prywatnego. Prawo zobowiązań część ogólna, t. 5, Warszawa [C.H. Beck] 2013.

Namitkiewicz J., Kodeks zobowiązań. Komentarz dla praktyki, t. 1, Łódź [Kolumna] 1949.

Olejniczak A. (red.), System prawa prywatnego. Prawo zobowiazań - część ogólna, t. 6, Warszawa [C.H. Beck] 2018.

Osajda K. (red.), Kodeks cywilny. Komentarz. Zobowiązania. Część ogólna, t. IIIA, Warszawa [C.H. Beck] 2017.

Pietrzykowski K. (red.), Kodeks cywilny, t. 2: Komentarz. Art. 4501088, Warszawa [C.H. Beck] 2018.

Poczobut J., Źródła prawa kolizyjnego dla umowy o arbitraż (w:) A. Szumański (red.), System prawa handlowego. Arbitraż handlowy, t. 8, Warszawa [C.H. Beck] 2015.

Popiołek W., Komentarz do art. 484 (w:) K. Pietrzykowski (red.), Kodeks cywilny, t. 2: Komentarz. Art. 450-1088, Warszawa [C.H. Beck] 2018.

Pyziak-Szafnicka M., Kilka uwag na temat modelu kary umownej (w:) J. Gudowski, K. Weitz (red.), Aurea praxis. Aurea theoria. Księga pamiątkowa ku czci Profesora Tadeusza Erecińskiego, t. 2, Warszawa [LexisNexis] 2011.

Radwański Z. (red.), System prawa cywilnego, t. 3, cz. 1: Prawo zobowiązań - część ogólna, Warszawa [C.H. Beck] 1981.
Rieble V., Staudingers Kommentar zum Bürgerlichen Gesetzbuch, t. 2, Berlin [Schweitzer] 1994.

Sinkiewicz A., Pojęcie i rodzaje szkody w polskim prawie cywilnym, „Rejent” 1998, nr 2(82), s. 60-64.

Szumański A. (red.), System prawa handlowego. Arbitraż handlowy, t. 8, Warszawa [C.H. Beck] 2015.

Szwaja J., Kara umowna wedtug Kodeksu cywilnego, Warszawa [Wydawnictwo Prawnicze] 1967.

Widerski P., Charakter prawny kary umownej wedtug prawa polskiego na tle ponadnarodowych uregulowań prawnych, „Studia Prawa Prywatnego" 2018, nr 2, s. 21-45.

Wiśniewski T., Komentarz do art. 484 (w:) J. Gudowski (red.), Kodeks cywilny. Komentarz, t. 3: Zobowiązania. Część ogólna, Warszawa [C.H. Beck] 2017.

Zagrobelny K., Komentarz do art. 484 (w:) E. Gniewek, P. Machnikowski (red.), Kodeks cywilny. Komentarz, Warszawa [C.H. Beck] 2017.

Zoll F., Pojęcie niewykonania i nienależytego wykonania zobowiązania oraz kwalifikowane postaci naruszenia zobowiązania $i$ ich skutki (w:) A. Olejniczak (red.), System prawa prywatnego. Prawo zobowiązań - część ogólna, t. 6, Warszawa [C.H. Beck] 2018. 